\title{
Bioekologi vektor demam berdarah dengue (DBD) serta deteksi virus dengue pada Aedes aegypti (Linnaeus) dan Ae. albopictus (Skuse) (Diptera: Culicidae) di kelurahan endemik DBD Bantarjati, Kota Bogor
}

\author{
Bioecology of dengue haemorrhagic fever vectors and dengue virus \\ detection in Aedes aegypti (Linnaeus) and Ae. albopictus (Skuse) \\ (Diptera: Culicidae) in endemic area of Bogor City
}

\section{Zahara Fadilla, Upik Kesumawati Hadi*, Surachmi Setiyaningsih}

Program Studi Parasitologi dan Entomologi Kesehatan, Institut Pertanian Bogor Jalan Agatis Kampus IPB Darmaga, Bogor 16680

(diterima September 2013, disetujui Oktober 2013)

\begin{abstract}
ABSTRAK
Demam berdarah dengue (DBD) merupakan salah satu penyakit yang disebabkan oleh virus dengue dan masih menjadi masalah kesehatan masyarakat di Indonesia. Penelitian ini dilakukan untuk mengetahui bioekologi Aedes spp. dan deteksi virus dengue pada nyamuk Aedes spp. di Kelurahan Bantarjati Kota Bogor. Penangkapan nyamuk dilakukan bulan April sampai Juli 2012. Pada nyamuk Aedes spp. dilakukan deteksi virus Dengue dengan teknik reverse transcriptionpolymerase chain reaction (RT-PCR) yang terdiri dari 2 tahap, yaitu tahap sintesis dan amplifikasi ${ }_{c}$ DNA serta tahap karakterisasi serotipe virus dengue. Penangkapan nyamuk Aedes aegypti (Linnaeus) dan Ae. albopictus (Skuse) dilakukan pada 200 rumah penduduk di daerah endemik DBD dengan metode umpan orang di dalam dan luar rumah. Kepadatan nyamuk Ae. aegypti dan Ae. albopictus tertinggi terjadi pada bulan April dengan puncak aktivitas mengisap darah pada jam 10:00-11:00. Virus dengue tidak terdeteksi pada nyamuk betina Aedes spp. yang ditangkap di Kelurahan Bantarjati Kota Bogor.
\end{abstract}

Kata kunci: Aedes spp., demam berdarah dengue, virus dengue, polymerase chain reaction

\begin{abstract}
Dengue hemorrhagic fever (DHF) is a viral disease that threatened community health in Indonesia. As part of an eradication program, it is important to learn the behavioral aspect of the disease vector. The aims of this study were to detect the presence of dengue virus in Aedes spp, at Bantarjati Village, Bogor City and to learn to bioecology of. Aedes aegypti (Linnaeus). Detection of dengue virus in Aedes spp. were done by reverse transcription-polymerase chain reaction (RT-PCR) technique that consist of two phase were synthesis phase and cDNA amplification and dengue virus serotipe characterization. The Ae. aegypti and Ae. albopictus (Skuse) mosquitoes were collected using the landing and resting moquito collection technique booth indoors and outdoors. The highest density of Ae. aegypti and Ae. albopictus were found in April and the peak activity was occurred at 10:00-11:00 am. Dengue virus was not detected in female mosquitoes Aedes spp.
\end{abstract}

Key word: Aedes spp., dengue hemorrhagic fever, polymerase chain reaction

\footnotetext{
*Penulis korespondensi: Upik Kesumawati Hadi. Program Studi Parasitologi dan Entomologi Kesehatan, Fakultas Kedokteran Hewan, Institut Pertanian Bogor, Jalan Agatis Kampus IPB Dramaga, Bogor 16680

Tel/Faks: (0251) 421784/629463, Email: upikke@gmail.com
} 


\section{PENDAHULUAN}

Demam berdarah dengue (DBD) merupakan salah satu penyakit viral penting yang ditularkan oleh nyamuk Aedes spp. Penyakit ini diketahui disebabkan oleh 4 tipe virus dengue, yaitu DEN-1, DEN-2, DEN-3, dan DEN-4 yang terkait dengan antigenik. Infeksi oleh salah satu serotipe virus tersebut akan memberikan kekebalan seumur hidup, namun tidak terhadap serotipe yang berbeda. Penderita DBD virus dengue banyak ditularkan pada penduduk daerah perkotaan terutama daerah tropis dan sub-tropis oleh nyamuk Aedes aegypti (Linnaeus), Ae. albopictus (Skuse) dan Ae. polynesiensis Marks (Perez et al. 1998; WHO 2001).

DBD masih menjadi masalah kesehatan masyarakat di Kota Bogor karena penderita penyakit tersebut dapat ditemukan sepanjang tahun dengan jumlah kasus paling tinggi di Kelurahan Bantarjati Kota Bogor. Kasus DBD di Kota Bogor dilaporkan selalu meningkat setiap tahun, yaitu 1807 penderita tahun 2007 (case fatality rate $[\mathrm{CFR}]=0,005 \%$ ), 1344 penderita tahun $2008(\mathrm{CFR}=0,006 \%)$, 1504 penderita tahun $2009(\mathrm{CFR}=0,006), 1769$ penderita tahun 2010 (CFR $=0,002 \%), 608$ penderita tahun $2011(0,001 \%)$, dan 1011 penderita tahun $2012(\mathrm{CFR}=0,001 \%)$. Tingginya kasus DBD di Kelurahan Bantarjati sangat berhubungan dengan keberadaan Aedes spp. dan virus dengue (DEN) yang terpelihara pada nyamuk vektor. Sampai saat ini serotipe virus dengue yang terdapat pada nyamuk Aedes spp. di Kelurahan Bantarjati Kota Bogor belum pernah dilaporkan.

Penelitian bioekologi Aedes spp. serta deteksi virus dengue perlu dilakukan pada nyamuk vektor di daerah endemik DBD. Deteksi virus dapat dilakukan dengan cara isolasi virus dari spesimen nyamuk. Deteksi dan identifikasi serotipe virus dilakukan dengan teknik reverse trancriptationpolymerase chain reaction (RT-PCR) yang telah dikembangkan sejak tahun 1990 (WHO 2009; Lanciotti et al. 1992). Penelitian ini bertujuan untuk melakukan studi bioekologi nyamuk vektor Aedes spp. dan deteksi virus dengue pada nyamuk Aedes spp. dari daerah endemik DBD Kelurahan Bantarjati Kota Bogor.

\section{BAHAN DAN METODE}

Penelitian dilakukan di Kelurahan Bantarjati, Kecamatan Bogor Utara, Kota Bogor. Penelitian bioekologi Aedes spp. dilakukan selama 4 bulan mulai bulan April sampai dengan bulan Juli 2012. Penelitian deteksi virus dengue dengan metode RTPCR dilakukan di Laboratorium Virologi, Fakultas Kedokteran Hewan, Institut Pertanian Bogor untuk mendeteksi DENV pada nyamuk Aedes spp.

\section{Pengumpulan larva dan nyamuk Aedes spp.}

Penangkapan larva Aedes spp. dilakukan 1 kali seminggu selama 4 bulan dengan mengamati tempat penampungan air (TPA) yang menjadi tempat perkembangbiakan larva nyamuk vektor DBD. Pengamatan larva dilakukan secara visual dengan menggunakan senter pada setiap kontainer yang diperiksa. Penangkapan nyamuk dewasa dilakukan 1 kali seminggu selama 4 bulan dari jam 06:00-18:00 sesuai dengan aktivitas nyamuk Aedes spp. mengisap darah. Metode yang digunakan untuk penangkapan nyamuk adalah dengan menggunakan umpan orang selama 20 menit, dan penangkapan nyamuk yang istirahat selama 5 menit pada 200 rumah penduduk. Spesimen larva dan nyamuk yang tertangkap diidentifikasi menggunakan kunci identifikasi larva dan nyamuk Aedes spp. Departemen Kesehatan RI tahun 2008.

\section{Deteksi virus dengue pada larva dan nyamuk dewasa}

Deteksi DENV pada nyamuk Aedes spp. diawali dengan proses ekstraksi RNA virus menggunakan QIAmp ${ }^{\circledR}$ Viral Mini Spin Kit (Qiagen) sesuai protokol kit QIAmp®. Deteksi virus DEN menggunakan generik primer virus D1 sebagai primer forward (5'TCAATATGCT GAAACGCGCGAGAAACCG3') dan primer virus D2 sebagai primer reverse (5' TGCACCAA CAGTCAATGTCTTCAGGTTC3') serta menggunakan type-specific primers TS1 (5'CGTCTCA GTGATCCGGGGG3'), TS2 (5'CGCCACAAGG GCCATGAACAG3'), dan TS3 (5'TAACATCATC ATGAGACAGAGC3') masing-masing akan mengamplifikasi region pada 482, 119, dan $290 \mathrm{pb}$ 
dari DEN-1, DEN-2, dan DEN-3 (Lanciotti et al. 1992).

Ada 2 metode RT-PCR yang digunakan dalam mendeteksi DENV, yaitu single-tube multiplex RT-PCR dan nested RT-PCR.

Metode single-tube multiplex RT-PCR. Hasil ekstraksi digunakan sebagai template RT-PCR. Amplifikasi dilakukan dengan menggunakan SuperScript III One-Step RT-PCR kit (Invitrogen). Pada proses amplifikasi disiapkan target DNA yang akan diamplifikasi pada volume $25 \mu$ l dengan komposisi campuran Master Mix $\mathrm{dH}_{2} \mathrm{O} 2,76 \mu 1$, 2x buffer 12,5 $\mu$ 1, Primer D1 (25 pmole), Primer TS1 (25 pmole), Primer TS2 (12,5 pmole), dan Primer TS3 (12,5 pmole), Enzyme $1 \mu 1$. Tabung dimasukkan ke dalam mesin PCR. Tahap PCR diawali dengan tahap reverse transcription $\left(50{ }^{\circ} \mathrm{C}\right.$, $60 \mathrm{~m})$ diikuti 40 siklus denaturasi $\left(94{ }^{\circ} \mathrm{C}, 30 \mathrm{~s}\right)$ annealing $\left(55^{\circ} \mathrm{C}, 1 \mathrm{~m}\right)$, dan ekstensi $\left(68^{\circ} \mathrm{C}, 2 \mathrm{~m}\right)$. (Harris et al. 1998; Wijayanti et al. 2006).

Metode nested RT-PCR. Amplifikasi pertama dilakukan dengan menggunakan SuperScript III One-Step RT-PCR kit (Invitrogen). Pada proses amplifikasi disiapkan target RNA yang akan diamplifikasi pada volume $25 \mu 1$ dengan komposisi campuran Master Mix $4 \mu \mathrm{l} \mathrm{dH}_{2} \mathrm{O}, 2 \mathrm{x}$ buffer $12,5 \mu$ l, Primer D1 (25 pmole), Primer D2 (25 pmole), Enzyme $1 \mu 1$ dan $5 \mu 1$ template. Tabung dimasukkan ke dalam mesin PCR. Proses amplifikasi yang kedua menggunakan DyNAzeme EXT DNA Polymerase kit dengan total volume $25 \mu$ l. Pada proses amplifikasi kedua disiapkan Master Mix dengan komposisi campuran 19,3 $\mu 1$ $\mathrm{dH}_{2} \mathrm{O}, 10 \mathrm{x}$ buffer $2,5 \mu 1$, dNTP $0,5 \mu 1$ Primer D1 (12 pmole), Primer TS3 (12 pmole), DyNAzeme $0,5 \mu \mathrm{l}$ dan amplicon hasil amplifikasi pertama. Tahap PCR diawali dengan tahap reverse transcription $\left(50{ }^{\circ} \mathrm{C}, 60 \mathrm{~m}\right)$ dilanjutkan dengan 35 siklus denaturasi $\left(94^{\circ} \mathrm{C}, 30 \mathrm{~s}\right.$, annealing $\left(55^{\circ} \mathrm{C}\right.$, $1 \mathrm{~m})$, ekstensi $\left(68^{\circ} \mathrm{C}, 2\right.$ menit) (Lanciotti et al. 1992; Wijayanti et al. 2006).

\section{Elektroforesis}

Hasil amplifikasi dielektroforesis pada gel agarose $1 \%$ dengan power supply pada posisi $120 \mathrm{~V}$ selama 45 menit. Loading buffer dan leader marker yang digunakan menggunakan produk Fermentas. Setelah dielektroforesis, gel agarose dimasukkan ke dalam alat transluminator ultra violet untuk melihat pita DNA virus DEN.

\section{Analisis data}

Data lapangan dan hasil identifikasi serotipe virus DEN dianalisis secara deskriptif dan disajikan dalam bentuk tabel, grafik, dan program excel. Kepadatan larva pada wadah yang ditemukan, dan kepadatan populasi nyamuk Aedes spp. dihitung untuk mengetahui perilaku mengisap darah dan perilaku istirahat.

\section{HASIL}

\section{Pengamatan habitat larva nyamuk Aedes spp.}

Pengamatan habitat larva dilakukan berdasarkan jenis wadah, letak wadah, bahan dasar dan warna wadah. Hasil pengamatan habitat larva (Tabel 1) diketahui bahwa jenis wadah TPA yang banyak digunakan oleh penduduk adalah bak mandi, ember, tempayan dan drum sebanyak 298 buah (75,25\%) dengan kepadatan larva Ae. aegypti dan Ae. albopictus tertinggi pada wadah drum (12,5\%) dan bak mandi (12,5\%). Wadah bukan TPA yang merupakan wadah bukan untuk menampung air sebanyak 98 buah $(24,75 \%)$ dengan persentasi kepadatan larva tertinggi pada ban bekas (100\%) sedangkan wadah alamiah tidak ditemukan di lokasi penelitian. Wadah yang positif mengandung larva Ae. aegypti di luar rumah memiliki kepadatan lebih tinggi (10,45\%) sedangkan Kepadatan larva Ae. albopictus di luar rumah (34,33\%). Bahan dasar yang memiliki kepadatan larva Ae. aegypti tertinggi ada pada wadah yang terbuat dari karet $(100 \%)$ dan larva Ae. albopictus memiliki kepadatan tertinggi pada bahan kayu (100\%). Pada larva Ae. albopictus warna wadah yang paling sering ditemukan larva adalah warna coklat $(58,33 \%)$ dan hitam $(15,28 \%)$, sedangkan larva Ae. aegypti tertinggi terdapat pada wadah berwarna bening $(31,25 \%)$, cokelat dan oranye $(25 \%)$.

\section{Kepadatan dan perilaku nyamuk Aedes spp. perilaku mengisap darah}

Puncak aktivitas Ae. aegypti mengisap darah di dalam rumah (UOD) terjadi pada jam 10:0011:00 (0,42 nyamuk/orang/jam) (Gambar 1). Hasil berbeda ditunjukan oleh puncak aktivitas nyamuk Ae. albopictus mengisap darah yang lebih banyak 
Tabel 1. Kepadatan larva Aedes spp. berdasarkan jenis habitat di Kelurahan Bantarjati

\begin{tabular}{|c|c|c|c|c|c|}
\hline \multirow{2}{*}{ Jenis wadah } & \multirow{2}{*}{$\sum$ Wadah } & \multirow{2}{*}{$\%$} & \multicolumn{3}{|c|}{ Container index (\%) } \\
\hline & & & Ae. aegypti & Ae. albopictus & Cx. quinquefasciatus \\
\hline \multicolumn{6}{|l|}{ TPA } \\
\hline Bak mandi & 144 & 36,7 & 13,89 & 1,39 & 0 \\
\hline Tempayan & 5 & 1,26 & 0 & 0 & 0 \\
\hline Ember & 141 & 35,61 & 3,55 & 4,26 & 0,71 \\
\hline Drum & 8 & 2,02 & 12,50 & 12,50 & 0 \\
\hline \multicolumn{6}{|l|}{ Non TPA } \\
\hline Kaleng bekas & 5 & 1,26 & 40 & 0 & 0 \\
\hline Ban bekas & 1 & 0,25 & 100 & 100 & 0 \\
\hline Vas/pot & 20 & 5,05 & 40 & 10 & 0 \\
\hline Kolam/aquarium & 22 & 5,56 & 9,09 & 27,27 & 4,55 \\
\hline Dispenser & 43 & 10,86 & 18,60 & 0 & 0 \\
\hline Potongan bambu & 1 & 0,25 & 0 & 100 & 0 \\
\hline Saluran air & 2 & 0,51 & 0 & 50 & 50 \\
\hline Tempat minum burung & 1 & 0,25 & 0 & 0 & 0 \\
\hline Barang bekas & 3 & 0,76 & 0 & 0 & 0 \\
\hline Total wadah & 396 & 100 & - & - & - \\
\hline
\end{tabular}



Waktu pengamatan

Gambar 1. Aktivitas mengisap darah Aedes aegypti di Kelurahan Bantarjati Kota Bogor Tahun 2012. $\rightarrow:$ UOD; $\rightarrow$ : UOL.

tertangkap saat mengisap darah di luar rumah (UOL) dengan 2 aktivitas puncak mengisap darah, yaitu pada jam 10:00-11:00 (0,42 nyamuk/orang/ jam) dan jam 14:00-15:00 (0,17 nyamuk/orang/ jam) (Gambar 2).

\section{Perilaku istirahat}

Jumlah nyamuk Ae. aegypti istirahat sedikit lebih banyak ditemukan di dalam rumah (54,05\%). Berbeda dengan Ae. albopictus lebih banyak ditemukan istirahat diluar rumah $(85,71 \%)$.

\section{Deteksi virus dengue pada nyamuk Aedes spp.}

Hasil pemeriksaan RT-PCR dengan metode single-tube multiplex terhadap sampel nyamuk menunjukan terdapat 3 sampel yang diduga mengandung serotipe DEN-3, yaitu sampel no 3, 5, dan 6 yang tampak pita DNA sangat tipis yang di amplifikasi menggunakan primer D1 dan primer TS1, TS2 dan TS3 (Gambar 3). Sampel nyamuk yang diduga mengandung virus DEN-3 ini kemudian diuji kembali dengan metode Nested PCR untuk memastikan hasil uji dengan metode singletube multiplex RT-PCR, namun hasilnya negatif 




Gambar 2. Aktivitas mengisap darah Aedes albopictus di Kelurahan Bantarjati Kota Bogor Tahun 2012. $\rightarrow: \mathrm{UO} ; \rightarrow-\mathrm{UOL}$.

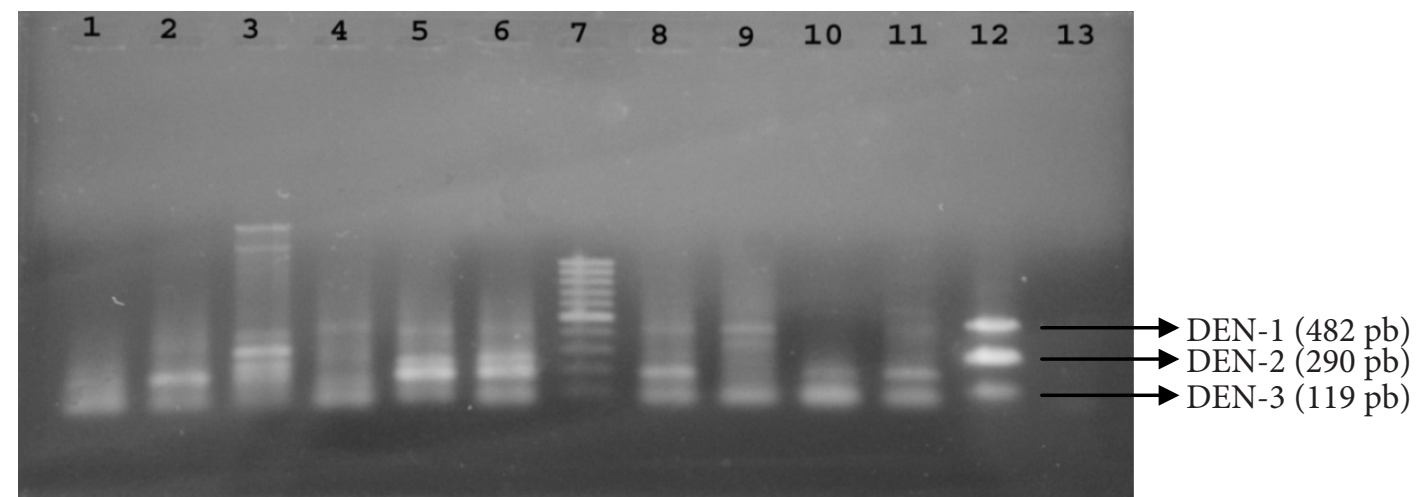

Gambar 3. Hasil elektroforesis metode Single-Tube Multiplex pada sampel nyamuk. Sampel nyamuk (lajur 1-6 dan lajur 8-11), marker $1 \mathrm{~kb}$ (lajur 7), kontrol positif (lajur 12), kontrol negatif (lajur 13). Menggunakan type-specific primers TS1, TS2, dan TS3.

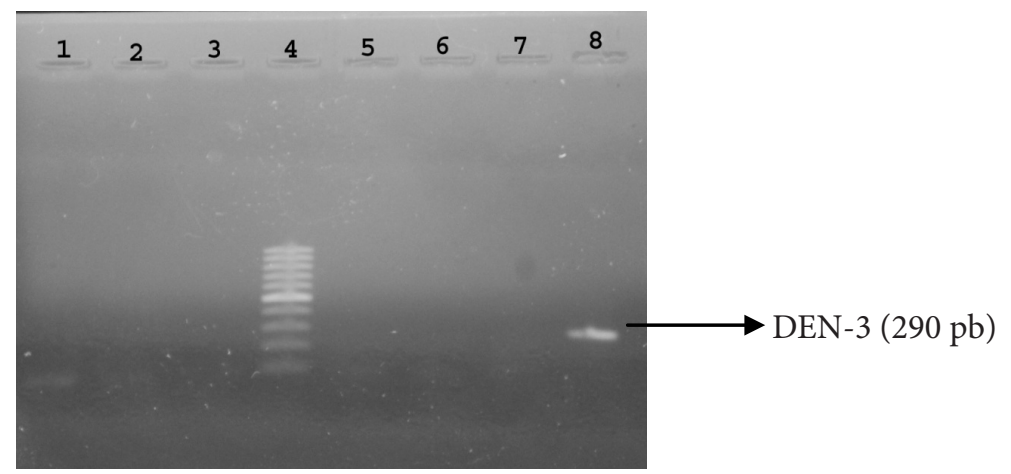

Gambar 4. Hasil elektroforesis metode Nested RT-PCR pada sampel nyamuk. Sampel nyamuk (lajur 1-3 dan 5-6), marker $1 \mathrm{~kb}$ (lajur 4), kontrol positif (lajur 8). Menggunakan type-specific primers TS1, TS2, dan TS3.

karena yang tampak setelah sampel dielektroforesis hanya pita kontrol $(+)$ positif sedangkan pita DNA pada sampel tidak tampak (Gambar 4).

\section{PEMBAHASAN}

Ada beberapa karakteristik wadah yang berpengaruh terhadap peletakan telur nyamuk Aedes spp., yaitu jenis, bahan, letak, warna, ukuran, dan kondisi wadah tertutup atau terbuka. Tempat potensial sebagai habitat larva nyamuk Ae. aegypti dan Ae. albopictus adalah wadah buatan manusia berisi air. Hasil penelitian menunjukkan bahwa jenis wadah (TPA) yang memiliki kepadatan larva Aedes spp. tertinggi adalah drum (12,5\%). Hal ini mirip dengan penelitian yang dilakukan Zulkarnaini et al. (2009) di Kota Dumai dengan persentase larva 
yang ditemukan pada drum cukup tinggi (61,76\%). Wadah ukuran besar seperti drum dan bak mandi merupakan TPA yang berpotensi sebagai tempat perkembangbiakan nyamuk Aedes spp. karena ukuran yang besar dan kurang memungkinkan untuk dikuras airnya secara rutin.

Wadah dengan kepadatan larva Ae. aegypti lebih tinggi terjadi di luar rumah $(10,45 \%)$, Kondisi tersebut dapat terjadi karena tempat bertelur Ae. aegypti sebagian besar adalah wadah buatan manusia yang ada di dalam ataupun sekitar lingkungan permukiman penduduk (WHO 2011). Hasil penelitian ini serupa dengan penelitian yang dilakukan oleh Idowu et al. (2010) di Nigeria bahwa larva Ae. aegypti lebih banyak ditemukan di luar rumah. Wonkoon et al. (2007) melaporkan di Thailand Ae. albopictus lebih menyukai bertelur pada wadah di luar rumah. Keberadaan wadah TPA baik yang berada di dalam dan di luar rumah berpotensi menjadi habitat nyamuk vektor Aedes spp. dan merupakan salah satu faktor yang berperan dalam penularan penyakit DBD (Fathi et al. 2005).

Larva Ae. aegypti lebih banyak ditemukan pada wadah yang terbuat dari karet (100\%). Hal ini sesuai dengan penelitian Hasyimi et al. (2009) yang melaporkan bahwa persentase larva Aedes spp. yang ditemukan pada ban bekas cukup tinggi, sedangkan larva Ae. albopictus lebih banyak ditemukan pada wadah yang terbuat dari kayu dan karet (100\%). Obenauer et al. (2010) menyatakan larva Ae. albopictus lebih menyukai air yang tergenang di tanah dan wadah yang terbuat dari bahan alami.

Warna wadah yang ditemukan dengan kepadatan nyamuk Aedes spp. tinggi adalah cokelat, hitam, dan bening. Kondisi warna yang gelap pada TPA memberikan rasa aman dan tenang bagi nyamuk atau terkadang warna gelap menyebabkan larva menjadi tidak terlihat sehingga kemungkinan untuk dibersihkan menjadi lebih kecil (Salim \& Febriyanto 2005). Warna bening yang ditemukan larva Ae. aegypti di lokasi penelitian mencapai $31,25 \%$. Persentase yang cukup tinggi ini terjadi karena wadah tidak berwarna di lokasi penelitian sering digunakan sebagai akuarium dan vas bunga sehingga kemungkinan wadah tersebut jarang atau lama tidak dibersihkan sehingga kepadatan larva cukup tinggi.
Perilaku mengisap darah nyamuk Aedes spp. hasil penelitian menunjukan bahwa nyamuk $A e$. albopictus lebih banyak tertangkap saat mengisap darah di luar rumah dengan puncak aktivitas pada jam 10:00-11:00 dan 14:00-15:00. Hasil penelitian ini sesuai dengan sifat nyamuk $A e$. albopictus yang zoofilik, yaitu spesies nyamuk kebun dan khususnya daerah pedesaan dengan habitat terutama daerah dengan vegetasi tanaman dan pohon, ketiak daun, ban, kaleng bekas, sampah dan wadah lain yang dapat menampung air (Guillaumot 2005; Ratigan 2000). Nyamuk Ae. aegypti mengisap darah lebih banyak di dalam rumah pada jam 10:00-11:00 dan 16:0017:00. Kondisi tersebut terjadi karena nyamuk Ae. aegypti bersifat antropofilik dan endofagik. Nyamuk Aedes spp. dilaporkan memiliki perilaku menghisap darah lebih dari satu orang (multiple bite), sehingga perilaku ini dapat meningkatkan keefektifan penyebaran virus dengue (WHO 2004). Nyamuk Ae. aegypti dilaporkan dominan di daerah perkotaan dan hidup di dalam rumah. Hasil penelitian menunjukan bahwa kepadatan nyamuk Ae. aegypti istirahat di dalam rumah lebih tinggi dan sesuai dengan penelitian Tandon \& Ray (2000) di India \& Perich et. al (2010) di Panama. Hasil tersebut menunjukan bahwa nyamuk Ae. aegypti bersifat endofilik. Nyamuk Ae. aegypti tertangkap saat istirahat banyak ditemukan pada pakaian yang digantung, gorden, jendela, dinding, lemari, bagian bawah meja, kursi, dan peralatan rumah tangga yang terdapat di dalam rumah.

Deteksi DNA dan serotipe virus dengue dilakukan dengan teknik RT-PCR. Penelitian ini dilakukan untuk deteksi serotipe virus dengue dari nyamuk dewasa Aedes spp. meliputi serotipe DEN1, DEN-2 dan DEN-3, karena menurut Prasetyowati \& Astuti (2010) serotipe virus dengue dominan teridentifikasi di kabupaten/kota di Provinsi Jawa Barat, yaitu DEN-1 (9,6\%), DEN-2 (55\%), DEN-3 $(29 \%)$. Serotipe yang paling sedikit teridentifikasi dilaporkan adalah DEN-4 (5,4\%).

Virus dengue pada penelitian ini tidak terdeteksi pada sampel nyamuk mungkin karena degradasi RNA virus, waktu penangkapan dan kejadian wabah, dan adanya pengasapan (fooging). Menurut Sasmono et al. (2012), faktor yang mempengaruhi tidak terdeteksinya virus DEN pada nyamuk 
Aedes spp. adalah terjadinya degradasi RNA. RNA virus DEN dipengaruhi oleh beberapa hal antara lain suhu yang tinggi atau rendah yang dapat mengganggu ketahanan virus di dalam tubuh nyamuk. Faktor kimiawi dan waktu viremia yang relatif singkat diduga dapat mempengaruhi isolasi virus DEN di dalam tubuh nyamuk. Degradasi RNA virus DEN pada nyamuk menyebabkan tidak terjadinya amplifikasi DNA untuk dapat mendeteksi serotipe virus DEN (Sasmono et al. 2012). Hasil negatif juga dapat disebabkan oleh waktu penangkapan yang tidak tepat saat terjadinya kasus sehingga nyamuk yang tertangkap di lapangan tidak mengandung virus DEN dan kemungkinan nyamuk yang ditangkap dari lapangan merupakan nyamuk yang baru mengalami eklosi dari pupa sehingga nyamuk tersebut belum sempat mengisap darah sehingga kemungkinan besar tidak mengandung virus. Andriyani (2009) juga tidak berhasil mendeteksi serotipe DEN3 di Kota Medan dari 100 sampel nyamuk yang diperiksa. Hal ini kemungkinan disebabkan oleh waktu penangkapan nyamuk di lapangan yang tidak tepat saat tidak terjadi KLB DBD. Penyebaran DBD sangat berhubungan dengan kepadatan dan penyebaran nyamuk vektor di suatu wilayah. Kelangsungan hidup vektor sangat dipengaruhi oleh ketersedian habitat sebagai tempat berkembangbiak vektor nyamuk, lingkungan fisik termasuk suhu, curah hujan, kelembaban, dan angin, serta lingkungan sosial khususnya perilaku masyarakat.

\section{KESIMPULAN}

Jenis wadah paling banyak ditemukan sebagai habitat larva Aedes spp. adalah jenis wadah bukan TPA $(60,61 \%)$. Nyamuk Ae. aegypti ditemukan mengisap darah di dalam rumah $(60,53 \%)$ dengan puncak kepadatan jam 10.00-11.00 (0,42 nyamuk/ orang/jam). Nyamuk Ae. albopictus lebih banyak tertangkap di luar rumah $(77,27 \%)$ dengan puncak aktivitas mengisap darah pada jam 10.00-11.00 (0,42 nyamuk/orang/jam). Perilaku istirahat nyamuk $A e$. aegypti cenderung lebih menyukai di dalam rumah dan Ae. albopictus lebih menyukai istirahat di luar rumah. Virus Dengue DEN-1, DEN-2, dan DEN-3 tidak ditemukan pada nyamuk betina Aedes spp.

\section{DAFTAR PUSTAKA}

Andriyani Y. 2009. Deteksi dan Penentuan Serotipe Virus Dengue Tipe-3 (DEN-3) dari Nyamuk Aedes aegypti Dengan Menggunakan Reverse Transcriptase-PCR (RT-PCR) di Kota Medan. Tesis. Medan: Universitas Sumatera Utara.

[Depkes RI] Departemen Kesehatan Republik Indonesia. 2008. Kunci Identifikasi Nyamuk Aedes. Jakarta: Direktorat Jendral Pengendalian Penyakit dan Penyehatan Lingkungan, Departemen Kesehatan RI.

Dinas Kesehatan Kota Bogor. 2012. Distribusi Kasus dan Kematian DBD Tahun 2007-2012. Bogor: Dinas Kesehatan Kota Bogor.

Guillaumot L. 2005. Arbovirus and their vectors in the Pacific-status report. Pacific Health Surveillance and Response 12:45-52.

Fathi, Keman S, Wahyuni CU. 2005. Peran faktor lingkungan dan perilaku terhadap penularan demam berdarah dengue di Kota Mataram. Jurnal Kesehatan Lingkungan 1:1-10.

Hasyimi M, Harmany, Nanny, Pangestu. 2009. Tempat-tempat terkini yang disenangi untuk perkembangbiakan vektor demam berdarah Aedes spp. Jurnal Pembangunan Manusia 1:71-76.

Harris, E, Roberts G, Smith L, Selle J, Kramer LD, Valle S, Sandoval E, Balmaseda A. 1998. Typing of dengue viruses in clinical specimens and mosquitoes by single-tube multiplex reverse transcriptase PCR. Journal of Clinical Microbiology 36:2634-2639.

Idowu OA, Adeleke MA, Aina TM. 2010. Evaluation of indoor breeding activities of mosquitos during the dry season in Abeokuta, Southwestern Nigeria. Jurnal of Enviromental Health Reaearch 12:25-30.

Kamgang B, Nchoutpouen E, Simard F, Paupy C. 2012. Notes on the blood-feeding behavior of Aedes albopictus (Diptera: Culicidae) in Cameroon. Journal Parasites \& Vectors 5:57. doi: http://dx.doi.org/10.1186/1756-3305-5-57.

Lanciotti RS, Calisher CH, Gubler DJ, Chang GJ, Vorndam AV. 1992. Rapid detection and typing of dengue viruses from clinical samples by using reverse transcriptase-polymerase chain reaction. Journal of Clinical Microbiology 30:545-551.

Obenauer PJ, Kaufman PE, Kline DL, Allan SA. 2010. Detection of and monitoring for Aedes albopictus (Diptera: Culicidae) in Suburban and Sylvatic habitats in North Central Florida using four sampling techniques. Environmental Entomology 39:1608-16. doi: 10.1603/EN09322. 
Perez, JGR, Clark GG, Gubler DJ, Reiter P, Sanders EJ, Vorndam AV. 1998. Dengue and dengue haemorrhagic fever. The Lancet 352:971-7. doi: http://dx.doi.org/10.1016/S0140-6736(97) 12483-7.

Perich MJ, Davila G, Turner A, Garcia A, Nelson M. 2000. Behavior of resting Aedes aegypti (Culicidae:Diptera) and its relation to ultra-low volume adulticide efficacy in Panama City, Panama. Journal of Medical Entomology 37:541546. doi: http://dx.doi.org/10.1603/0022-258537.4.541.

Prasetyowati H, Astuti EP. 2010. Serotipe virus dengue di tiga kabupaten/kota dengan tingkat endemisitas DBD berbeda di Proponsi Jawa Barat. Aspirator 2:120-124.

Ratigan CW. 2000. The Asian Tiger Mosquito (Aedes albopictus): Spatial, Ecological and Human Implications in Southeast Virginia. Tesis. Blacksburg: Virginia Polytechnic Institute and State University.

Salim M, Febriyanto. 2005. Survey jentik Aedes aegypti di Desa Saung Naga Kabupaten Oku. Jurnal ekologi kesehatan 6:602-607.

Sasmono T, Yohan B, Setainingsih TY, Aryati, Wardhani P, Rantam FA. 2012. Identifikasi genotipe dan karakterisasi genome virus dengue di Indonesia untuk penentuan prototipe virus bahan pembuatan vaksin dengue berbasis strain Indonesia. Di dalam: Prosiding Seminar Insentif Riset SINas. Tersedia pada: http://biofarmaka. ipb.ac.id/biofarmaka/2013/PIRS\%202012\%20 -\%20file-KO-TeX_35.pdf. [diakses 21 Oktober 2014].
Tandon N, Ray S. 2000. Host feeding pattern of Aedes aegypti and Aedes albopictus in Kolkata, India. Dengue Bulletin 24:117-120.

[WHO] World Health Organization. 2001. Panduan lengkap: Pencegahan dan Pengendalian Dengue dan Demam Berdarah Dengue. Jakarta: EGC.

[WHO] World Health Organization. 2004. Demam Berdarah Dengue Diagnosis, Pengobatanm Pencegahan dan Pengendalian. Jakarta: EGC.

[WHO] World Health Organization. 2009. Dengue: Guidelines for Diagnosis, Treatment, Prevention and Control. Prancis: WHO.

[WHO] World Health Organization. 2011. Regional Office For South - East Asia. Comprehensive Guidelines For Prevention and Control Of Dengue And Dengue Hemorrhagic Fever. Revised And Expended Edition. Regional Office for South East Asia.

Wijayanti N, Wibawa T, Nirwati H, Haryanto A, Sutaryo. 2006. Rapid detection and molecular typing of dengue virus by using multiplexNested-RT-PCR. Indonesian Journal of Biotechnology 2:928-932.

Wongkoon S, Jaroensutasinee M, Jaroensutasinee K, Preechaporn W. 2007. Development sites of Aedes aegypti and Ae. albopictus in Nakhon si Thammarat, Thailand. Dengue Bulletin 31:141152.

Zulkarnaini, Siregar YI, Dameria. 2009. Hubungan kondisi sanitasi lingkungan rumah tangga dengan keberadaan jentik vektor Dengue di daerah rawan demam berdarah dengue Kota Dumai tahun 2008. Journal of Enviromental Science 2:115-124. 